\title{
Sedimentary control and reservoir response of marine continental transitional shale: Taking the eastern margin of Ordos Basin as an example in China
}

\author{
ZHUANGSEN WANG
}

China University of Mining and Technology, Beijing

Presenting Author: 18810361039@163.com

Marine-continental transitional shale gas contains significant resources, but scant areas have been developed economically. To date, the exploration and development of transitional shale gas and the study of its geological evaluation of China's shale gas are still in the initial stage. Therefore, the pore structure characterization, evolution of paleoenvironmental and potential of high-quality shales generation from the Carboniferous to Permian (mainly of Benxi, Taiyuan and Shanxi formations) in the east margin of Ordos Basin, China, was systematically studied by integrated analysis including low temperature $\mathrm{N}_{2}$ and $\mathrm{CO}_{2}$ adsorption/desorption analysis, trace elements and organic geochemical testing. The results show that these transitional shales are generally in mature to high mature stage with good gas generation potential. Furthermore, the gas generated from the interbedded coal seams in the Upper Paleozoic is a stable gas supply for interbedded shales. The pores in the transitional shale are mainly occurred in clay minerals, and the organic matter pores are relatively poor and isolated. The pore shapes are dominantly intra-particle and interparticle pores of slit-shaped as identified. The micropores and mesopores are abundant for all the shale samples, accounting for more than $90 \%$ of the total pore volume and specific surface area. A generally anaerobic paleoenvironment can be observed from the Upper Carboniferous to Lower Permian, as identified from ratios of $\mathrm{V} / \mathrm{Cr}, \mathrm{Ni} / \mathrm{Co}, \mathrm{U} / \mathrm{Th}, \delta \mathrm{U}$, and $\mathrm{V} /(\mathrm{V}+\mathrm{Ni})$, even though the degree of oxidation increases from the lower to upon strata. The $\mathrm{Sr} / \mathrm{Cu}$ and $\mathrm{Rb} / \mathrm{Sr}$ values reflect that the climate was mainly humid and warm, while the Taiyuan show a more arid climate than the Benxi and Shanxi formations. The $\mathrm{Sr} / \mathrm{Ba}$ values indicate a marine - transitional - continental environments transition from the Benxi-Taiyuan-Shanxi and Xiashihezi formations. The $\mathrm{Ba}_{\mathrm{XS}}$ results indicate that paleoproductivity in the study area gradually increased. The primary productivity and an anoxic environment in surface water contributed to the organic matter enrichment of shales in the study area. The results provide a geochemical basis for further study of marine-continental transitional shales in the Ordos Basin and supply recommendations for the optimization of high-quality shales production in similar basins around the world. 